\title{
Healthcare and unhealthy eating among children aged under two years: data from the National Health Survey, Brazil, 2013
}

\author{
Patricia Constante Jaime 1 \\ Paulo Germano de Frias 2 \\ Helena Oliveira da Cruz Monteiro 3 \\ Paulo Vicente Bonilha Almeida 4 \\ Deborah Carvalho Malta 5
}

\footnotetext{
Faculdade de Saúde Pública.Universidade de São Paulo.Av. Dr. Arnaldo, 715.São Paulo, SP, Brasil. CEP: 01.246-904. E-mail: constant@usp.br

2 Instituto de Medicina Integral Professor Fernando Figueira.Recife, PE, Brasil.

3 Instituto Brasileiro de Geografia e Estatística.Rio de Janeiro, RJ, Brasil.

4 Coordenação-Geral de Saúde da Criança e Aleitamento Materno.Departamento de Ações Programáticas Estratégicas.Secretaria de Atenção à Saúde.Ministério da Saúde. Brasília, DF, Brasil.

5 Faculdade de Enfermagem.Universidade Federal de Minas Gerais. Belo Horizonte, MG, Brasil.
}

\begin{abstract}
Objectives: to examine indicators relating to access to child health care and markers of unhealthy patterns of eating in Brazilian children aged under two years and to set these in the context of the National Health System's current child healthcare agenda.

Methods: a descriptive cross-sectional study using data from the 2013 National Health Survey. Prevalences and confidence intervals of $95 \%$ (CI95\%) were estimated for the total population, Brazilian macroregions and urban or rural location of household.

Results: a first medical consult before the seventh day of life was reported in only $28.7 \%$ of children. Supervision of growth and child development was carried out primarily at basic health units (57.2\%; C195\%: 54.8-59.6). Theneonatal screening, newborn hearing screening and red reflex tests were conducted with a frequency of 70.8\% (CI95\%: 69.0-72.7), 56.0\% (CI95\%: 53.8-58.3) and 51.1\% (C195\%: 48.9-53.3), respectively. Disparities were found in preventive health care, with lower access among children living in rural households or in the North and Northeast regions. Soda consumption was reported for $32.3 \%$ and consumption of biscuits or cake for $60.8 \%$ of children, indicating premature introduction of unhealthy foods into the child's diet.

Conclusions: the findings point to disparities in access to child healthcare and a high prevalence of unhealthy eating habits in infancy.

Key words Health surveys, Child care, Food consumption, Child, Brazil
\end{abstract}




\section{Introduction}

The first two years of life are known to be a crucial period in growth and child development for health promotion and the prevention of diseases in adult life. ${ }^{1}$ As a result, child health indicators have been used as lifestyle markers. ${ }^{2}$

Child healthcare in Brazil evolved from the topdown mother-child programs of the 1970 s and 80 s, especially after the introduction of the National Health System (SUS), into an approach based on integrated care, human rights, overcoming vulnerabilities, reducing morbidity and mortality and promoting health and quality of life. 3,4

Considerable progress in the living conditions of children is part of the new reality in Brazilian public health. It is estimated that there was a reduction in child mortality rates of $5.5 \%$ per year between 1980 and $1990,4.4 \%$ up to the year 2000,5 and $4.7 \%$ between 2000 and 2010.6 The fourth of the Millennium Development Goals was met in 2012 and, in 2014, the rate stood at 14.4 deaths per 1000 live births. 7 Furthermore, discrepancies in child mortality rates between regions and states have be reduced, especially in the 2000s. 6 Likewise, there has been a substantial increase in vaccination coverage, the prevalence of maternal breastfeeding and the reduction of malnutrition. ${ }^{2}$ These successes can be attributed to the expansion and improvement of health interventions, in particular the family health strategy, 8 and social and economic changes. This has had a real impact on the social determinants of health. 5,9

The National Demography and Health Survey (PNDS) 10 conducted in 2006 investigated morbidity and mortality, access to services, health procedures and nutrition in children under five years of age. It found that SUS was the predominant service used, with $87 \%$ of cases of diarrhea and $70 \%$ of fever or coughing. In terms of eating habits, it noted the early introduction of unhealthy foods, with high levels of consumption of soda $(40.5 \%)$, fried food $(39.4 \%)$, snacks (39.4\%) and sweets (37.8\%) between one and three times per week. ${ }^{11}$ Since food habits are established primarily in the first years of life, the consumption of unhealthy food in this phase influences eating behaviors associated with non-communicable chronic diseases throughout life. 12

The first National Health Survey (PNS), conducted in 2013 in a partnership between the Ministry of Health, the Oswaldo Cruz Foundation and the Brazilian Institute of Geography and Statistics (IBGE), enabled exploration of up-to-date information on child health, as it included children under two years of age in its population sample. 13 The aims of the present study are to explore indicators produced by the PNS relating to access to child healthcare and markers of unhealthy eating patterns in Brazilian children aged under two years and to set these in the context of the National Health Service's current child healthcare agenda.

\section{Methods}

A descriptive cross-sectional study based on secondary data from the PNS, a household-based populational survey included in the IBGE's Integrated System for Household Research (SIPD), which, by using its master sample enables greater geographical spread and precision for specific health estimates. The master sample is a set of area units that are selected to meet the needs of various household surveys, such as the PNS. These units are called primary sampling units (PSUs) and are based on information from the 2010 Population Census. The PNS sample is thus representative of Brazil, its macro regions, urban and rural populations and capital cities and data collection occurred between August 2013 and February 2014.

The sampling was grouped into three stages, with stratification of the PSUs. The census districts or group of districts were the PSUs, the households were the second stage units and residents aged 18 years or over the third stage units. Children aged under two years were identified in the second stage, when a fixed number of permanent private residences in each PSU were selected by simple random sampling using the National Register of Addresses for Statistical Purposes. All children aged under two years resident in the sample households were included in the study. 13

After completion of data collection, records of interviews were obtained for 64,348 households, with a loss rate of $20.8 \%$. Sample weightings were defined for the PSUs, the households and all their residents. Methodological details of the PNS have been described in a previous publication. 13

Module L of the PNS questionnaire refers to the health of children aged under two years of age. It contains information on the use of health services, preventive care relating to vaccines, neonatal screening tests for metabolic and congenital diseases and impaired hearing and eyesight (neonatal screening, newborn hearing screening and red reflex tests, respectively), vitamin and minerals supplements, maternal breastfeeding and food consumed in the previous day. The information on the children was given by the mothers or guardians. Indicators 
were selected that presented a coefficient of variance less than or equal to $10 \%$ at each level of stratification desired, as made available by the IBGE.

The variables were grouped into two blocks: (1) indicators of access to child health care and (2) markers of an unhealthy eating pattern. The variables making up the first block were: first medical consult up to $7^{\text {th }}$ day after discharge from maternity, the neonatal screening test in the first week of life of the newborn, the newborn hearing screening and red reflex tests in the first month, three doses of tetravalent vaccine at the age of 6 to 12 months, medicinal supplementation with iron sulfate at the age of 6 to 23 months and location of supervision of growth and development.

The second block used two markers of an unhealthy eating pattern among children aged under two years, the consumption of soda or artificial juice and the consumption of biscuits or cake. These markers were obtained from three questions in module L of the PNS questionnaire: (question L01713) "Can you tell me if [CHILD'S NAME] has eaten biscuits or cake since yesterday morning?", (question L01707) "Can you tell me if [CHILD'S NAME] has drunk artificial juice between yesterday morning and this morning?" or (question L01715): "Can you tell me if [CHILD'S NAME] has eaten or drunk other food between yesterday morning and this morning?"

Prevalences were estimated for indicators of access to child healthcare and markers of eating habits, presented as percentages (\%), with their respective $95 \%$ confidence intervals (CI95\%) for Brazil, macro regions (Central West, South, Southeast, Northeast and North) and location of household (urban or rural). Stata version 11.0 was used, employing the survey command to analyze data from complex samples. The PNS was approved by the National Ethics Commission for Research involving Human Beings (no 328.159/2013).

\section{Results}

Table 1 shows indicators of access to child health care. A first medical consult up to the seventh day after discharge from maternity was reported for $28.7 \%$ of the children studied (CI95\%: 26.6-30.9) but was lower in the Northeast (17.7\%; CI95\%:15.120.4 ) and North regions (21.8\%; CI95\%: 18.8-24.9) and for rural households (20.0\%; CI95\%: 16.3-23.7).

Neonatal screening was carried out with a national frequency of 70.8\% (CI95\%: 69.0-72.7), $56.0 \%$ (CI95\%: 53.8-58.3) and 51.1\% (CI95\%:48.953.3) for the neonatal screening, newborn hearing screening and red reflex tests, respectively. There were found to be disparities in access to such preventive care procedures, with lower access among children resident in rural households or in the North and Northeast regions of the country. On the other hand, there was high coverage for the neonatal screening in the South (83.5\%; CI95\%: 78.7-88.4) and Southeast (84.7\%; CI95\%: 81.6; 87.8) regions (Table 1).

Three doses of the tetravalent vaccine was found to have been administered in $75.9 \%$ (CI95\%: 73.0 78.7) of children aged between six and twelve months, varying from $70.1 \%$ (CI95\%: 63.4-76.9) in the North region to $85.3 \%$ in the South region (CI95\%: 79.4-91.3). The frequency of administration of the tetravalent vaccine was higher in children resident in rural households than among those in urban households, 83.3\% (CI95\%: 78.8-87.8) versus $74.3 \%$ (CI95\%: 71.0; 77.6), as shown in Table 1.

In terms of the use of health services to accompany the growth and development of children, the basic SUS health units (57.2\%; CI95\%: 54.8-59.6) were the most frequently reported locations, followed by private consults/clinics $(26.5 \%$; CI95\%: 24.2-28.8). Growth and development were not accompanied in around $7 \%$ of the children studied (6.8\%: CI95\%: 5.7-7.9) (Figure 1).

Iron sulfate supplements were reported for 57.9\% (CI95\%: 55.3-60.5) of children aged between 6 and 23 months, varying from $40.3 \%$ (CI95\%: 35.645.0 ) in the North region to $69.9 \%$ (CI95\%: 65.074.7) in the Southeast (Figure 2).

In terms of markers of unhealthy child diet, the consumption of soda on the previous day was reported for around one in three of children aged less than two years in the study (32.3\%; CI95\%: 30.2 34.4 ), with the Northeast region having the lowest frequency (25.5\%; CI95\%: 22.2-28.8). The consumption of biscuits or cake was reported for $60.8 \%$ of children (CI95\%: 58.6-63.0). No significant difference was found in the distribution of the markers for eating habits investigated between children resident in urban and rural households (Table 2).

\section{Discussion}

The information obtained by the PNS shows that there are still many challenges to be overcome, despite the efforts of programs and policies, since the 1980 s, to improve child health care, based on a care model involving broader access and avoiding fragmentation. ${ }^{2-4}$ The low frequency, less than one third, of first consult for the newborn within the first week of life is an expression of the insufficient ties 


\section{Table 1}

Percentage distribution of indicators of access to child healthcare, by macroregion and location of household. National Health Survey, Brazil. 2013.

\begin{tabular}{|c|c|c|c|c|c|c|c|c|c|c|}
\hline \multirow{3}{*}{ Variable } & \multicolumn{8}{|c|}{ Indicator of access to child healthcare } & & \\
\hline & \multicolumn{2}{|c|}{$\begin{array}{l}\text { 1st medical consult with } \\
\text { in } 7 \text { days after discharge from } \\
\text { maternity }\end{array}$} & \multicolumn{2}{|c|}{$\begin{array}{l}\text { Neonatal screening } \\
\text { test in first week of } \\
\text { life }\end{array}$} & \multicolumn{2}{|c|}{$\begin{array}{l}\text { Newborn hearing } \\
\text { screening test in } \\
\text { first month of life }\end{array}$} & \multicolumn{2}{|c|}{$\begin{array}{l}\text { Red reflex test in first } \\
\text { month of life }\end{array}$} & \multicolumn{2}{|c|}{$\begin{array}{l}\text { Three doses of } \\
\text { tetravalent vaccine in } \\
\text { first year of life }\end{array}$} \\
\hline & $\%$ & $(\mathrm{Cl} 95 \%)$ & $\%$ & $(\mathrm{Cl} 95 \%)$ & $\%$ & $(\mathrm{Cl} 95 \%)$ & $\%$ & $(\mathrm{Cl} 95 \%)$ & $\%$ & $(\mathrm{Cl} 95 \%)$ \\
\hline \multicolumn{11}{|l|}{ Macroregion } \\
\hline North & 21.8 & $(18.8-24.9)$ & 56.4 & $(51.8-61.1)$ & 35.3 & $(30.9-39.7)$ & 30.4 & $(26.4-34.3)$ & 70.1 & $(63.4-76.9)$ \\
\hline Northeast & 17.7 & $(15.1-20.4)$ & 53.8 & $(50.1-57.5)$ & 37.5 & $(33.8-41.3)$ & 28.9 & $(25.6-32.1)$ & 80.3 & $(75.5-85.2)$ \\
\hline Southeast & 33.5 & $(28.8-38.3)$ & 84.7 & $(81.6-87.8)$ & 70.3 & $(66.2-74.5)$ & 71.1 & $(67.1-75.1)$ & 70.5 & $(64.8-76.3)$ \\
\hline South & 44.0 & $(38.4-49.5)$ & 83.5 & $(78.7-88.4)$ & 77.6 & $(72.2-82.9)$ & 68.5 & $(62.8-74.2)$ & 85.3 & $(79.4-91.3)$ \\
\hline Central West & 31.0 & $(26.5-35.4)$ & 69.1 & $(64.5-73.7)$ & 50.8 & $(46.4-55.3)$ & 41.4 & $(36.7-46.0)$ & 76.2 & $(70.8-81.6)$ \\
\hline \multicolumn{11}{|l|}{ Location of } \\
\hline \multicolumn{11}{|l|}{ household } \\
\hline Urban & 30.4 & $(27.9-32.9)$ & 73.2 & $(71.2-75.3)$ & 60.6 & $(58.1-63.2)$ & 54.9 & $(52.5-57.4)$ & 74.3 & $(71.0-77.6)$ \\
\hline Rural & 20.0 & $(16.3-23.7)$ & 58.4 & $(53.7-63.1)$ & 32.2 & $(27.9-36.5)$ & 31.3 & $(26.7-35.9)$ & 83.3 & $(78.8-87.8)$ \\
\hline Brazil & 28.7 & $(26.6-30.9)$ & 70.8 & $(69.0-72.7)$ & 56.0 & $(53.8-58.3)$ & 51.1 & $(48.9-53.3)$ & 75.9 & $(73.0-78.7)$ \\
\hline
\end{tabular}

Source: IBGE, Director of Research, Coordinator of Work and Income, National Health Survey 2013.

Figure 1

Percentage distribution of locations for accompanying growth and development of children. National Health Survey, Brazil. 2013.

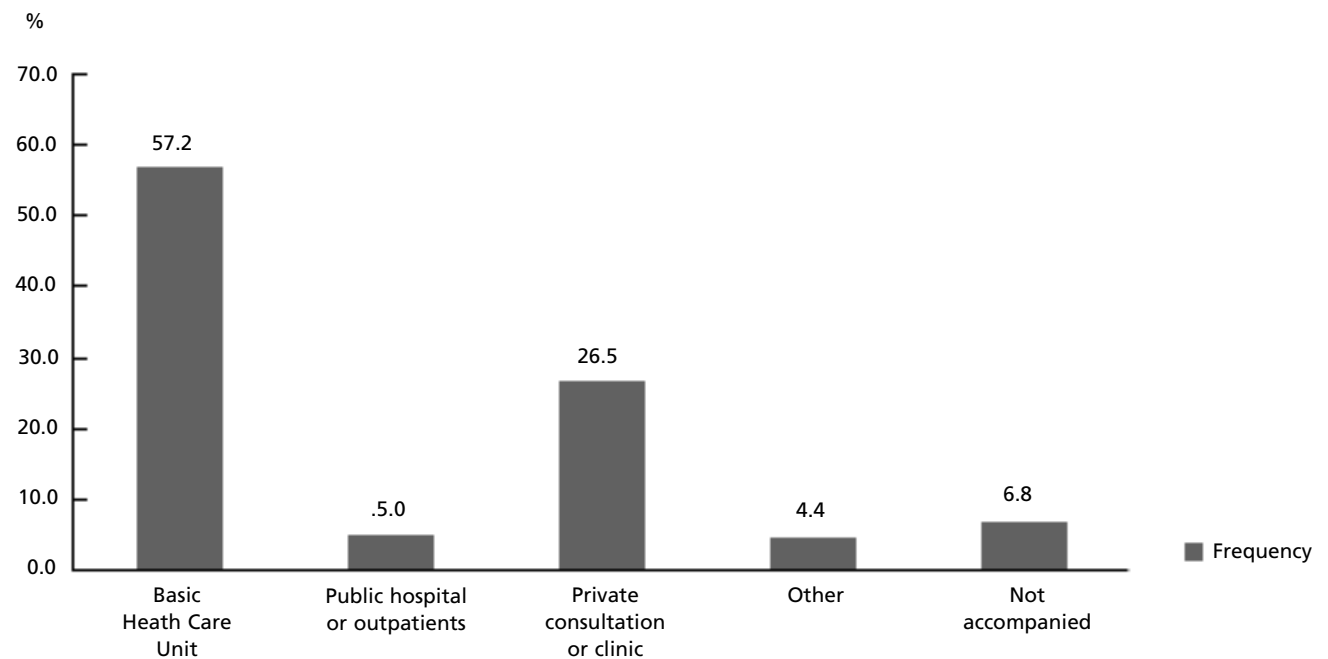

Source: IBGE, Director of Research, Coordinator of Work and Income, National Health Survey 2013. 


\section{Figure 2}

Proportion of children aged 6 to 23 months receiving medicinal iron sulfate supplements, by macroregion and location of household. National Health Survey, Brazil. 2013.

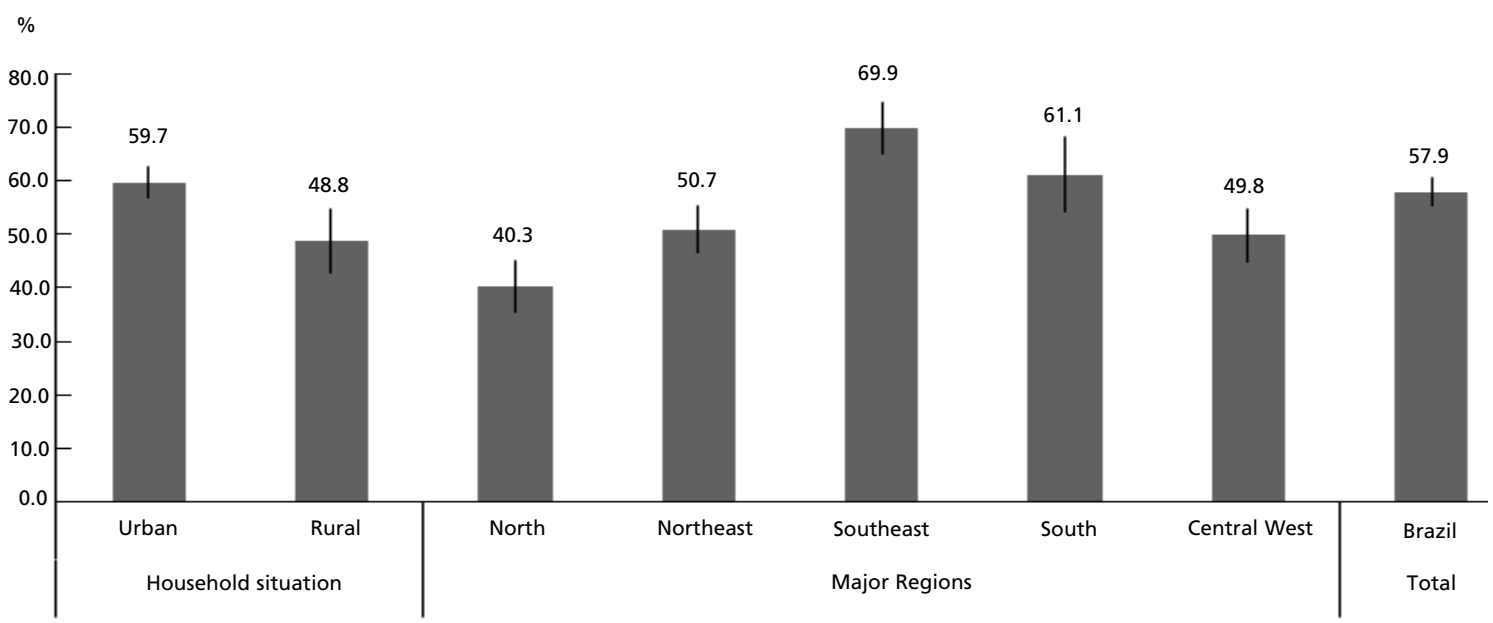

Source: IBGE, Director of Research, Coordinator of Work and Income, National Health Survey 2013.

\section{Table 2}

Percentage distribution of markers of unhealthy eating, by macroregion and location of household. National Health Survey, Brazil. 2013

\begin{tabular}{|c|c|c|c|c|}
\hline \multirow{3}{*}{ Variable } & \multicolumn{4}{|c|}{ Marker of unhealthy eating } \\
\hline & \multicolumn{2}{|c|}{$\begin{array}{l}\text { Consumption of soda or artificial juice } \\
\text { in children aged under } 2 \text { years }\end{array}$} & \multicolumn{2}{|c|}{$\begin{array}{l}\text { Consumption of biscuits or cake in } \\
\text { children aged under } 2 \text { yearss }\end{array}$} \\
\hline & $\%$ & $(\mathrm{Cl} 95 \%)$ & $\%$ & $(\mathrm{Cl} 95 \%)$ \\
\hline \multicolumn{5}{|l|}{ Macroregion } \\
\hline North & 32.9 & $(28.8-37.0)$ & 51.9 & $(47.7-56.2)$ \\
\hline Northeast & 25.5 & $(22.2-28.8)$ & 58.8 & $(54.7-62.8)$ \\
\hline Southeast & 34.2 & $(30.0-38.4)$ & 64.3 & $(60.2-68.3)$ \\
\hline South & 38.5 & $(32.3-44.6)$ & 60.4 & $(54.9-65.8)$ \\
\hline Central West & 37.4 & $(32.8-41.9)$ & 65.3 & $(60.6-69.9)$ \\
\hline \multicolumn{5}{|c|}{ Location of household } \\
\hline Urban & 32.5 & $(30.1-34.9)$ & 61.8 & $(59.4-64.2)$ \\
\hline Rural & 31.3 & $(27.1-35.4)$ & 55.7 & $(50.5-60.8)$ \\
\hline Brazil & 32.3 & $(30.2-34.4)$ & 60.8 & $(58.6-63.0)$ \\
\hline
\end{tabular}

Source: IBGE, Director of Research, Coordinator of Work and Income, National Health Survey 2013. 
between maternity hospitals and primary care and shows that timely access to the health network to ensure integral care of mother, child and family has not been effected. The first consult is supposed to provide guidance and support for exclusive maternal breastfeeding, immunization, supervision of growth and development, confirmation of neonatal screening, identification of risks and vulnerabilities and the need to reinforce the family support network, among other actions. ${ }^{14}$

The fact that most children had undergone the neonatal screening, newborn hearing screening and red reflex tests suggests a more promising scenario for neonatal screening related to preventive health care achieving broader coverage in the Southeast and South regions. Of the three tests evaluated, the neonatal screening test had higher frequencies in all Brazilian regions and should ideally be carried out between the 3 rd and 5 th day of life at a primary health care (PHC) unit or in a maternity hospital, if the child is still hospitalized. In the case of abnormal results, the child should be referred to the referral service available in all Brazilian states. 14 Despite the recommendation, the study Situational Diagnosis of the National Neonatal Screening Program in the Brazilian States shows that there is incipient integration of PHC units with the specialized service, with the exception of the States of Minas Gerais and São Paulo, The managers of the National Neonatal Screening Program (PNTN) in the states just if the gaps in neonatal screening test coverage by noting the absence of information and recording of supplementary health tests, which are not widely available at the PNTN and cultural traits that lead to resistance to or dismissal of neonatal screening, among other factors. ${ }^{15}$ The public services conduct $54 \%$ of all neonatal screenings, charitable organizations $44 \%$ and the private sector only $2 \% .15$

Coverage of the red reflex test could be extended if it were incorporated as part of the first physical examination of the newborn in the maternity hospital and basic care, although more than $80 \%$ of the teams evaluated by the National Program for Improved Access to and Quality of Basic Care (PMAQ-AB) did not have ophthalmoscopes. ${ }^{16}$ Equally important, the newborn hearing screening test, which tracks hearing loss and is recommended for all newborns, should be carried out in all hospitals and maternity units. The PHC team is responsible for ascertaining whether the test has been carried out and for referring the case to a referral service when necessary. 14

2013 PNS data suggest that challenges remain in terms of access to neonatal screening tests, especially for children living in rural households and in the North and Northeast regions of the country. The provision of services for people with disabilities is another gap in SUS care.17 To overcome this problem, 2012 saw the creation of a care network for people with disabilities (Living without Limits) that aims to expand and improve neonatal screening and the establishment of Specialized Rehabilitation Centers (CER), to provide comprehensive care for physical, intellectual, auditory and visual disabilities. ${ }^{17}$

Vaccination is a preventive care service recommended throughout the world and is an obligatory component of health programs. Its effectiveness depends on high coverage and equal access to vaccines, thereby providing both individual protection and collective immunity. 18 Coverage of the tetravalent vaccine (against diphtheria, whooping cough, tetanus and type b Haemophilus influenzae, with 3 doses in children aged under one year) has been recommended for evaluation of national immunization programs. 19 The 2013 PNS data show that the frequency of administration of three doses of the tetravalent vaccine in children aged one year has reached around three quarters of the population in two years. Administrative data obtained through the National Immunization Program Information System (SI-PNI) have shown that coverage of tetravalent was $93.8 \%$ for Brazil, in 2012, varying from $91.1 \%$ in the North region to $95.1 \%$ in the Southeast. 19 Other population studies have found an even higher proportion than that observed in the 2013 PNS of children receiving doses of the tetravalent vaccine at the recommended age. A study by Luhm et al. 20 estimated coverage of $96.7 \%$ among 12 -month-old children in the Municipality of Curitiba. However, methodological differences may compromise the comparability of results.

Iron deficiency anemia in childhood is a public health problem that affects developed and developing countries alike. ${ }^{21}$ According to data from the National Children's and Women's Demography and Health Survey, the prevalence of anemia was $20.9 \%$ among children under five years of age and $24.1 \%$ in those aged between 6 and 23 months. The highest prevalences observed in the PNDS were for the Northeast (25.5\%), Southeast $(22.6 \%)$ and South $(21.5 \%)$ regions. ${ }^{10}$ There are reports that the prevalence of anemia may be higher than $50 \%$ in children in some regions of Brazil or in specific populations. 22 As a result, the World Health Organization recommends strategies additional to promoting healthy eating to ensure adequate intake of iron. Prophylactic supplementation with iron sulfate is the primary and most traditional strategy for preventing 
and treating iron deficiency anemia 23 and has been recommended by the SUS, since 2005 , for all pregnant women and children aged 6 to 24 months through the National Iron Supplementation Program. The findings of the 2013 PNS show that iron sulfate supplements were reported for more than half of the children aged 6 to 23 months, a figure higher than that observed in the 2006 PNDS $(31.5 \%$; CI95\%: 29.4-33.8). Improved access to mineral supplements at PHC units may explain the increased frequency of children receiving such supplements. However, regional differences are still marked by inequality in access to services, as demonstrated by the wide difference found between children receiving supplements in the North $(40.3 \%)$ and Southeast $(69.9 \%)$ regions. Data from the 2012 PMAQ-AB show that $68.0 \%$ health unit pharmacies are stocked with iron sulfate, varying from $65.9 \%$ in the Center West to $73.4 \%$ in the South region. 24 In slightly more than $40 \%$ of the children who did not use iron sulfate to prevent anemia this may be related to basic care professionals not prescribing it, problems of access to medication, low adherence to medication owing to factors such as the disagreeable taste, darkening of the teeth and feces and abdominal discomfort. 25

In terms of indicators of child diet, there was a high frequency of consumption of markers of an unhealthy eating pattern among children aged under two years: soda consumption in a third of children and consumption of biscuits or cake in more than half. These findings corroborate the trend towards early introduction of unhealthy food in children's diets identified in the 2nd Survey of the Prevalence of Maternal Breastfeeding in Brazilian Capitals and the Federal District, which found a frequency of 11.6\% (CI95\%: 10.5 - 12.8) for consumption of soda and $71.7 \%$ (CI95\%: 69.9-73.5) for biscuits and/or snacks, in the 9 to 12 month age group. 26 The PNS findings regarding markers of unhealthy child diet in terms of geographical distribution (macro region and location of household) corroborate previous evidence, from PNDS 2006 that suggest higher consumption of soda and cookies among children aged 6 to 59 months residing in the South and Southeast regions and in urban households. ${ }^{11}$

Unhealthy eating habits in childhood, characterized by the consumption of ultra-processed foods with a high sugar, sodium and fat content, have a negative impact on child health, with inadequate consumption of micronutrients 27 and increased risk of over weight and chronic non-communicable diseases associated with poor diet. 12 Vitolo et al.28 argue that exposure to unhealthy food in early infancy molds habits and food preferences for the rest of life and recommend that strategies to promote healthy eating be developed by PHC. Intervention studies aiming to train health professionals to provide counseling on maternal breastfeeding and complementary healthy eating have been proven to be effective. ${ }^{28}$ It is, however, still of vital importance to consolidate the health promotion and healthy eating agenda in basic health care, furthering educational activities and counseling on maternal breastfeeding and healthy eating throughout life and permanent education of workers. Such practices can be backed up by dissemination and use of guidelines and technical tools such as the healthy eating guides adopted in the country. 29

The present study has a number of limitations involving possible measurement bias owing to the method used to evaluate food consumption, which may be affected by lack of memory on the part of the informant with regard to the child's eating habits. Neither was it possible to explore indicators of maternal breastfeeding and healthy eating, such as the consumption of fruit, vegetables and beans, as the study was restricted to child food consumption variables with variation coefficients less than or equal to $10 \%$, at each level of stratification desired. Children's eating habits are presented only from the point of view of unhealthy consumption, without considering habits known to promote child health.

Another limitation stems from the lack of indicators to describe child healthcare in an integrated fashion. The data made available by the PNS were used to present and discuss in dicators of use of health services and preventive care related to vaccines, neonatal screening and iron supplements. These indicators were taken here to be markers of the current pattern of access to child healthcare, even though their ability to aid analysis of the specific agendas related to them is limited. For example, although it is well known that markers of growth and child development are not accompanied with the same frequency and quality in basic care and that growth is more often accompanied than development, 30 the present study, which dealt with secondary data, was unable to explore these two segments independently as is proposed in technical guidelines. 14

On the other hand, the examination of data from a population study as extensive as the 2013 PNS made it possible to conduct a more up-to-date and contextualized analysis of the phenomenon of interest and gave rise to reflections regarding the use of services and eating habits in the provision of child healthcare.

In conclusion, the results show the importance of 
monitoring child health indicators and the performance of services. Advances were found in the coverage of indicators related to more integrated care, with broad-ranging preventive care actions. However, inequalities were found to persist in access to services and health procedures, with lower access for children residing in the North and Northeast regions and in rural households. Inadequate eating behaviors, related to the consumption of food associated with the development of non-communicable chronic diseases, were common in the children studied. These results may aid decision-making to improve child healthcare, with a view to promoting health and equality and the prevention of diseases associated with a poor diet throughout life.

\section{Acknowledgements}

The authors are thankful to the Department of Surveillance of Non-Communicable Diseases and Disorders, the Secretary of Health Surveillance and the Ministry of Health for funding this research and to the National Science and Technology Development Board (CNPq) for research productivity grants awarded to PCJ and DCM.

\section{References}

1. Black RE, Victora CG, Walker SP, Bhutta ZA, Christian P, Onis M, Ezzati M, Grantham-McGregor S, Katz J, Martorell R, Uauy R, the Maternal and Child Nutrition Study Group. Maternal and child under nutrition and overweight in low-income and middle-income countries. Lancet. 2013; 382: 427-51.

2. Victora CG, Aquino EML, Leal MC, Monteiro CA, Barros FC, Szwarcwald CL. Maternal and child health in Brazil: progress and challenges. Lancet. 2011; 377: 1863-76.

3. Figueiredo GLA, Mello DF de. Atenção à saúde da criança no Brasil: aspectos da vulnerabilidade programática e dos direitos humanos. Rev Latino-am Enfermagem. 2007; 15 (6): 1171-6.

4. Brasil. Ministério da Saúde. Portaria no 1.130 , de 5 de agosto de 2015. Institui a Política Nacional de Atenção Integral à Saúde da Criança (PNAISC) no âmbito do Sistema Único de Saúde. Diário Oficial da União. Brasília, DF, 6 de agosto de 2015 .

5. Victora CG, Barreto ML, Leal MC, Monteiro CA, Schmidt MI, Paim J, Bastos FI, Almeida C, Bahia L, Travassos C, Reichenheim M, Barros FC, and the Lancet Brazil Series Working Group. Health conditions and health-policy innovations in Brazil: the way forward. Lancet.2011; 377: 201153.

6. Frias PG, Szwarcwald CL, Souza Jr PRB, Almeida WS, Lira PIC. Correção de informações vitais: estimação da mortalidade infantil, Brasil, 2000-2009. Rev Saúde Pública. 2013; 47(6): 1048-58.

7. IBGE (Instituto Brasileiro de Geografia e Estatística). Taxas de mortalidade infantil. Projeção da População do Brasil - 2013. [acesso em 22 set 2015]. Disponível em: http://brasilemsintese.ibge.gov.br / populacao / taxas-demortalidade-infantil.

8. Aquino R, Oliveira NF, Barreto ML. Impact of the family health program on infant mortality in Brazilian municipalities. Am J Public Health. 2009; 99: 87-93.

9. Rasella D, Aquino R, Santos CAT, Paes-Sousa R, Barreto ML. Effect of a conditional cash transfer programme on childhood mortality: a nationwide analysis of Brazilian municipalities. Lancet. 2013: 382: 57-64.

10. Brasil. Ministério da Saúde. Pesquisa Nacional de

Demografia e Saúde da Criança e da Mulher - PNDS 2006: dimensões do processo reprodutivo e da saúde da criança. Ministério da Saúde, Centro Brasileiro de Análise e Planejamento. Brasília, DF; 2009.

11. Bortolini GA, Gubert MB, Santos LMP. Consumo alimentar entre crianças brasileiras com idade de 6 a 59 meses. Cad Saúde Pública. 2012; 28(9): 1759-71.

12. Fall CH, Borja JB, Osmond C, Richter L, Bhargava SK, Martorell R, Stein AD, Barros FC, Victora CG, COHORTS Group. Infant-feeding patterns and cardiovascular risk factors in young adulthood: data from five cohorts in lowand middle-income countries. Int J Epidemiol. 2011; 40(1): 47-62.

13. Souza-Júnior PRB, Freitas MPS, Antonaci GA, Szwarcwald CL. Desenho da amostra da Pesquisa Nacional de Saúde 2013. Epidemiol Serv Saúde.2015; 24(2): 207-16.

14. Brasil. Ministério da Saúde. Secretaria de Atenção à Saúde. Departamento de Atenção Básica.Saúde da criança: crescimento e desenvolvimento. Brasília, DF; 2012. 272 p. (Cadernos de Atenção Básica, no 33 ).

15. Núcleo de Ações e Pesquisa em Apoio DiagnósticoNUPAD. Diagnóstico Situacional do Programa Nacional de Triagem Neonatal nos estados brasileiros: relatório técnico / Núcleo de Ações e Pesquisa em Apoio Diagnóstico NUPAD. Belo Horizonte: NUPAD, 2013. [acesso em 28 set 2015]. Disponível em: http://www.nupad.medicina.ufmg. $\mathrm{br} / ? \mathrm{p}=5699$.

16. Garnelo L, Lucas ACS, Parente RCP, Rocha ESC, Gonçalves MJF. Organização do cuidado às condições crônicas por equipes de Saúde da Família na Amazônia. Saúde debate [online]. 2014; 38: 158-72.

17. Magalhães Júnior HM. Redes de atenção à saúde: rumo à integralidade. Divulg Saúde Debate. 2014; 52: 15-37.

18. Delamonica E, Minujin A, Gulaid J. Monitoring equity in immunization coverage. Bull World Health Organ. 2005; 83(5): 384-91.

19. Rede Interagencial de Informação para a Saúde (RIPSA). Indicadores e Dados Básicos - Brasil - 2012. Indicadores de cobertura. Proporção de crianças vacinadas na faixa etária recomendada - F.13 - 2012. [acesso em 28 set 2015]. Disponível em: http://tabnet.datasus.gov.br/cgi/deftohtm. exe?idb2012/f13.def. 
20. Luhm KR, Cardoso MRA, Waldman EA. Cobertura vacinal em menores de dois anos a partir de registro informatizado de imunização em Curitiba, PR. Rev Saúde Pública. 2011; 45(1): 90-8.

21. McLean E, Cogswell M, Egli I, Wojdyla D, Benoist B. Worldwide prevalence of anaemia, WHO Vitamin and Mineral Nutrition Information System, 1993-2005. Public Health Nutr.2009; 12(4): 444-54.

22. Vieira RCS, Ferreira HS. Prevalência de anemia em crianças brasileiras, segundo diferentes cenários epidemiológicos. Rev Nutr. 2010;23(3): 433-44.

23. World Health Organization. United Nations University, United Nations Children's Fund. Iron deficiency anaemia: assessment, prevention, and control: a guide for programme managers. WHO; 2001.

24. Brasil. Ministério da Saúde. Secretaria de Atenção à Saúde. Departamento de Atenção Básica. Retratos da Atenção Básica no Brasil - 2012.Gestão da Atenção Básica. Volume 2 - Insumos e Medicamentos nas Unidades Básicas de Saúde. Brasília: Ministério da Saúde, 2015. [acesso em 28 set 2015]. Disponível em http://dab.saude.gov.br/portaldab/ biblioteca.php?conteudo=publicacoes/retratos_ab_2_vol_2.

25. Bortolini GA, Vitolo MR. Baixa adesão à suplementação de ferro entre lactentes usuários de serviço público de saúde. Pediatria (São Paulo). 2007; 29(3): 176-82.

26. Brasil. Ministério da Saúde. Secretaria de Atenção à Saúde.
Departamento de Ações Programáticas e Estratégicas. II Pesquisa de Prevalência de Aleitamento Materno nas Capitais Brasileiras e Distrito Federal. Brasília, DF; 2009.

27. Brekke K, Odijki JV, Ludvigsson J. Predictors and dietary consequences of frequent intake of high-sugar, low-nutrient foods in 1-year-old children participating in the ABIS study. Br J Nutr. 2007; 97: 176-81.

28. Vitolo MR, Louzada ML, Rauber F, Grechi P, Gama CM. Impacto da atualização de profissionais de saúde sobre as práticas de amamentação e alimentação complementar. Cad Saúde Pública. 2014; 30 (8): 1695-707.

29. Brasil. Ministério da Saúde. Secretaria de Atenção à Saúde. Departamento de Atenção Básica. Dez passos para uma alimentação saudável: guia alimentar para crianças menores de dois anos: um guia para o profissional da saúde na atenção básica. 2 ed. Brasília, DF; 2013.

30. Alves CRL, Lasmar LMLBF, Goulart LMHF, Alvim CG, Maciel GVR, Viana MRA, Colosimo EA, Carmo GAA do, Costa JGD da, Magalhães MEN, Mendonça ML, Beirão MMV, Moulin ZS. Qualidade do preenchimento da Caderneta de Saúde da Criança e fatores associados. Cad Saúde Pública. 2009; 25 (3), 583-95.

Received on january 5, 2016

Final version submitted on march 31, 2016

Approved on april 7, 2016 